\title{
Indolyl-Pyridinyl-Propenone-Induced Methuosis through the Inhibition of PIKFYVE
}

\author{
Hyelim Cho, ${ }^{*},{ }^{\dagger}, \odot$ Erin Geno, ${ }^{\dagger, \|}$ Maude Patoor, ${ }^{\dagger}$ Adam Reid, ${ }^{\dagger}$ Rick McDonald ${ }^{\dagger}$ Marc Hild, ${ }^{*}{ }^{\dagger}$
} and Jeremy L. Jenkins* ${ }^{* \dagger}$

${ }^{\dagger}$ Chemical Biology and Therapeutics, Novartis Institutes for BioMedical Research, 181 Massachusetts Avenue, Cambridge, Massachusetts 02139, United States

${ }^{\ddagger}$ Department of Chemistry, Johns Hopkins University, 3400 N. Charles Street, Baltimore, Maryland 21218, United States

\section{Supporting Information}

ABSTRACT: Methuosis is a form of nonapoptotic cell death characterized by the accumulation of macropinosome-derived vacuoles. Herein, we identify PIKFYVE, a class III phosphoinositide (PI) kinase, as the protein target responsible for the methuosisinducing activity of indolyl-pyridinyl-propenones (3-(5-methoxy-2-methyl-1H-indol-3-yl)1-(4-pyridinyl)-2-propen-1-one). We further characterize the effects of chemical substitutions at the 2- and 5-indolyl positions on cytoplasmic vacuolization and PIKFYVE binding and inhibitory activity. Our study provides a better understanding of the mechanism of methuosis-inducing indolyl-pyridinyl-propenones.

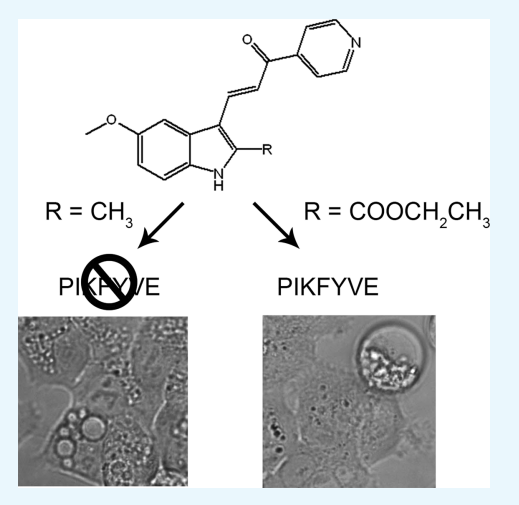

\section{INTRODUCTION}

Methuosis is a form of nonapoptotic cell death triggered by alterations in the trafficking of clathrin-independent endosomes and is associated with vacuolization of macropinosome and endosome compartments. ${ }^{1}$ Methuosis was initially defined in glioblastoma cells expressing activated Ras, ${ }^{2}$ but several studies have reported the features of methuosis in a broad spectrum of cancer cells including gastric carcinoma cells and osteosarcoma cells. ${ }^{3,4}$ The vacuoles generated during methuosis are distinct from autophagosomes and show characteristics of enlarged macropinosomes. Vacuolated cells eventually undergo caspaseindependent cell death initiated by the dysregulation of micropinocytosis. ${ }^{2}$

Previous investigations found that indolyl-pyridinyl-propenones (also referred to as indole-based chalcones) trigger methuosis. ${ }^{5}$ Specifically, 3-(5-methoxy-2-methyl-1H-indol-3yl)-1-(4-pyridinyl)-2-propene-1-one (MOMIPP) was identified as an initial exemplar tool compound. Follow-up structureactivity relationship (SAR) studies defined key features associated with three phenotypic classifications, namely, the induction of methuosis, vacuolization without cell death, ${ }^{6}$ and disruption of microtubules leading to apoptosis. ${ }^{7}$ Selected substitutions on the indole at position 2 or moving the methoxy group from position 5 to $6^{8}$ redirected the mode of cytotoxicity from distinctive methuosis to microtubule disruption with little observable effect on vacuoles. However, the protein target(s) of the compounds that prompt the methuosis phenotype have not been identified. In this study, we identified PIKFYVE, a class III phosphoinositide (PI) kinase, as at least one candidate protein that when inhibited triggers vacuolization, a hallmark of methuosis.

PI homeostasis is tightly regulated because the spatiotemporal restriction of different PI species is crucial for membrane trafficking within both the secretory and endocytic pathways. ${ }^{9,10}$ Disruption of endosome or macropinosome trafficking has been shown to induce cellular vacuolization. ${ }^{11}$ PI synthesis involves phosphorylating/dephosphorylating positions D3, D4, and/or D5 of their inositol ring by various lipid kinases and phosphatases. ${ }^{10}$ Accordingly, the inhibition of select lipid kinases or phosphatases by chemical or genetic perturbation can induce cellular vacuolization. ${ }^{12,13}$

\section{RESULTS AND DISCUSSION}

To explore whether indolyl-pyridinyl-propenones disrupt PI homeostasis by inhibiting a specific inositol kinase or phosphatase, we used a competition binding assay to quantitatively measure interactions between the lead compound MOMIPP and 22 inositol kinases including clinically relevant mutants (Table 1). The competition binding assay showed that at $10 \mu \mathrm{M}$, MOMIPP competes away all binding of inositol kinases PIKFYVE and PIP5K1C as compared to the control.

To further assess the binding potency and specificity, we calculated binding constants $\left(K_{\mathrm{d}}\right)$ against PIKFYVE and PIP5K1C with a standard dose-response curve (Figure 1).

Received: February 2, 2018

Accepted: February 23, 2018

Published: June 5, 2018 
Table 1. Lipid Kinase Competition Assay for 22 Inositol Kinases Including Clinically Relevant Mutants ${ }^{a}$

\begin{tabular}{lc}
\multicolumn{1}{c}{ target } & \% control \\
PIK3C2B & 76 \\
PIK3C2G & 39 \\
PIK3CA & 99 \\
PIK3CA(C420R) & 100 \\
PIK3CA(E542K) & 98 \\
PIK3CA(E545A) & 82 \\
PIK3CA(E545K) & 81 \\
PIK3CA(H1047L) & 72 \\
PIK3CA(H1047Y) & 92 \\
PIK3CA(I800L) & 72 \\
PIK3CA(M1043I) & 98 \\
PIK3CA(Q546K) & 82 \\
PIK3CB & 46 \\
PIK3CD & 66 \\
PIK3CG & 54 \\
PIK4CB & 87 \\
PIKFYVE & 0 \\
PIP5K1A & 61 \\
PIP5K1C & 06 \\
PIP5K2B & 50 \\
PIP5K2C & 96 \\
VPS34 & 06
\end{tabular}

${ }^{a}$ MOMIPP $(10 \mu \mathrm{M})$ was used for the competition. Data are shown as $\%$ control, where lower numbers indicate more competition between the control compound and MOMIPP. \% control was calculated as follows. (MOMIPP signal - positive control signal)/(negative control signal - positive control signal $) \times 100$. Negative control $=\mathrm{DMSO}$ ( $100 \%$ control); positive control $=$ control compound that binds specifically to each kinase ( $0 \%$ control).

In this assay, MOMIPP exhibited a $K_{\mathrm{d}}$ of $5.3 \mathrm{nM}$ against PIKFYVE, whereas the $K_{\mathrm{d}}$ against PIP5K1C was $>15000 \mathrm{nM}$, suggesting that MOMIPP specifically binds PIKFYVE with strong potency. Because previous SAR studies ${ }^{7}$ of methuosisinducing activity resulted in three classes of indolyl-pyridinylpropenones with distinct cellular phenotypes, we synthesized compounds from each class to confirm cellular phenotypes and characterize PIKFYVE inhibition (Table 2).

As previously characterized, ${ }^{7}$ class 1 compounds (2a, 2c) induced cellular vacuolization without causing cell death, class 2 compounds (1a; MOMIPP, 2b) induced cellular vacuolization and cell death via methuosis, and class 3 compounds (2l) induced cell death without showing distinct cellular vacuolization, consistent with prior reports of tubulin modulation (Figures 2, 3, and summarized in Table 2). To explore the correlation between the cellular vacuolization phenotype and the binding activity against PIKFYVE, we calculated binding constants $\left(K_{\mathrm{d}}\right)$ against PIKFYVE with a standard doseresponse curve.

In this assay, class 1 compounds (2a, 2c) exhibited $K_{d}$ of 23 and $51 \mathrm{nM}$, respectively, and class 2 compounds (1a; MOMIPP, 2b) exhibited $K_{\mathrm{d}}$ of 6.9 and $6.5 \mathrm{nM}$, respectively, whereas the $K_{\mathrm{d}}$ of class 3 compound (2l) was $>500 \mathrm{nM}$. The $K_{\mathrm{d}}$ of free acid compound (2o) was $46 \mathrm{nM}$ (Figure 3 and summarized in Table 2). These results show that compounds with the cellular vacuolization phenotype (class 1 and 2) strongly bind PIKFYVE. Compounds with carboxylic acid substitutions at $R_{2}$ (class 3) do not show the cellular vacuolization phenotype. Compound 21 , a tubulin modulator, ${ }^{7}$ displays a weak binding activity against PIKFYVE but triggers cell death. The related compound (2o) binds PIKFYVE with strong in vitro potency but likely loses the cellular activity because of the limited cellular permeability.

PIKFYVE is a $240 \mathrm{kD}$ lipid kinase that phosphorylates the D5 position in endosomal phosphatidylinositol-3-phosphate (PI3P) to yield 3,5-bisphosphate (PI(3,5)P2). ${ }^{14}$ To determine whether MOMIPP directly inhibits the PIKFYVE kinase activity, we performed an in vitro kinase assay with the purified PIKFYVE full-length protein. MOMIPP potently inhibited the PIKFYVE kinase activity $\left(\mathrm{IC}_{50}=5.05 \mathrm{nM}\right)$, whereas the class 3 compound (2l) had a reduced activity $\left(\mathrm{IC}_{50}=446 \mathrm{nM}\right)$ toward PIKFYVE (Figure 4). This result is consistent with the PIKFYVE binding assay where MOMIPP showed a stronger binding activity $\left(K_{\mathrm{d}}=6.9 \mathrm{nM}\right)$ in comparison to the class 3 compound (21) ( $\left.K_{\mathrm{d}}=540 \mathrm{nM}\right)$ (Figure 3 and Table 2).

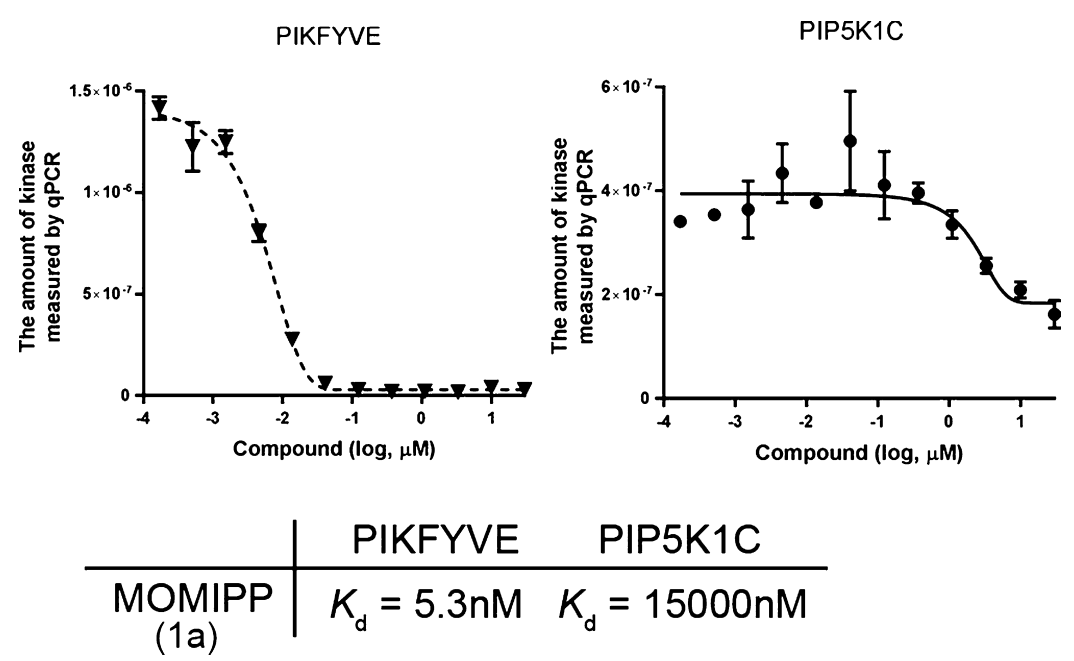

Figure 1. Lipid kinase competition assay for PIKFYVE and PIP5K1C. Compound-kinase interactions were quantitated by quantitative PCR (qPCR) that detects the associated DNA label on each kinase as described in the Experimental Section. The amount of kinase measured by qPCR is plotted against the corresponding MOMIPP concentration. Binding constants $\left(K_{\mathrm{d}}\right)$ were calculated with a standard dose-response curve using the Hill equation ${ }^{12}$ as follows. Response $=$ background $+($ signal - background $) /\left(1+\left(K_{\mathrm{d}}^{\text {Hill slope }}\right) /\left(\right.\right.$ dose $\left.\left.^{\text {Hill slope }}\right)\right)$. The Hill slope was set to -1 . 
Table 2. Summary of Compound Activity ${ }^{a}$

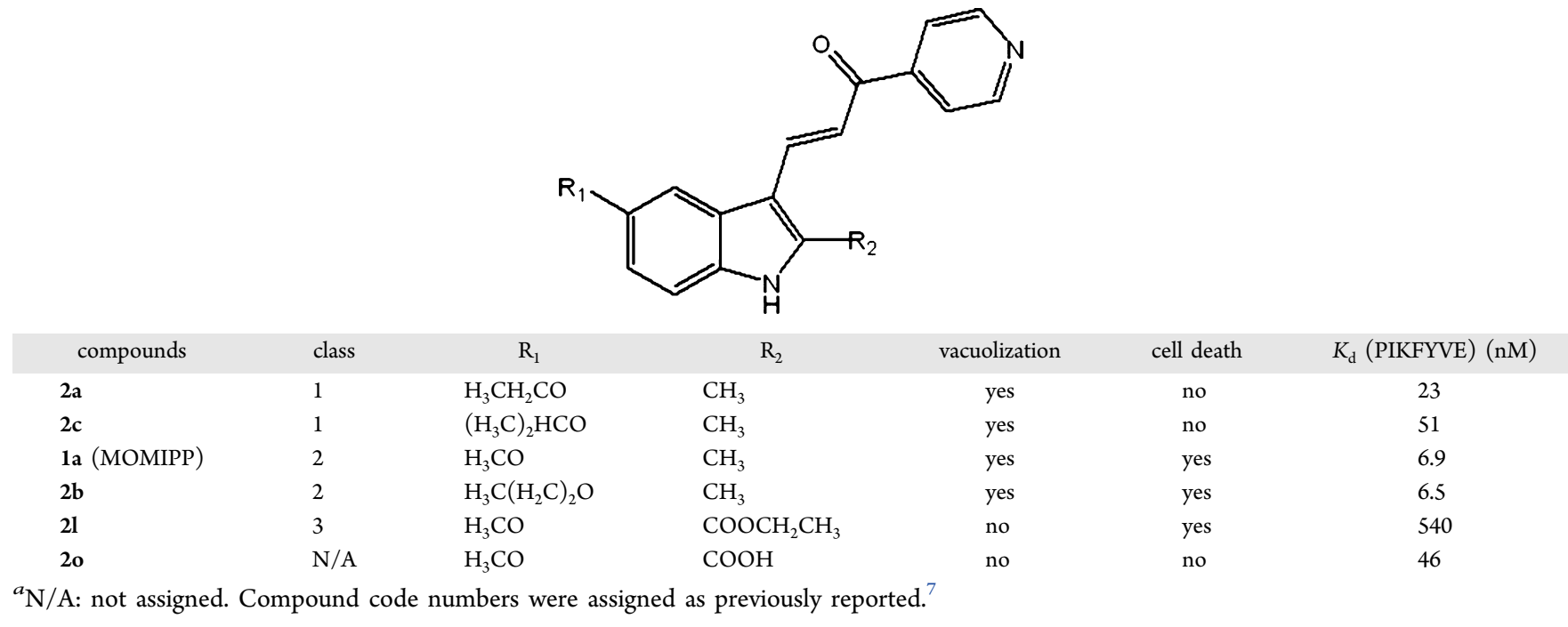

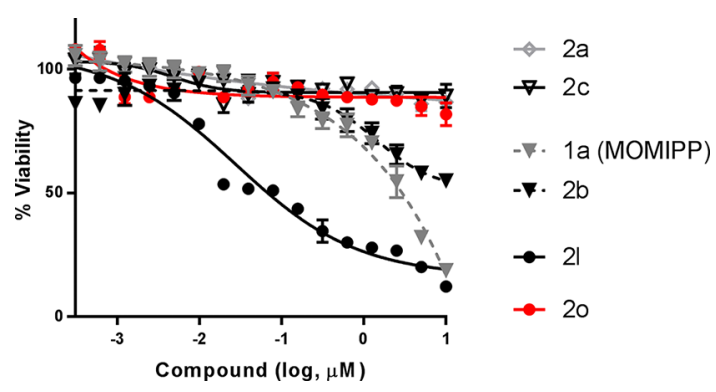

Figure 2. Effects of selected indolyl-pyridinyl-propenones on cell viability. Percent viability relative to vehicle [dimethyl sulfoxide (DMSO)] control after treatment for $72 \mathrm{~h}$ with indicated concentrations of compounds. Error bars indicate mean \pm SD of at least three replicates.

The genetic manipulation of PIKFYVE with CRISPR (clustered regularly interspaced short palindromic repeats)mediated genome editing (Figure 5A) and chemical perturbation of PIKFYVE activity using apilimod (Figure 5B) also showed similar vacuolization. These results effectively demonstrate that MOMIPP and its analogues (class 1 and class 2 compounds) trigger cellular vacuolization by inhibiting the PIKFYVE kinase activity.

In conclusion, we showed that MOMIPP binds PIKFYVE and inhibits its kinase activity. The preliminary SAR study effectively demonstrates that the binding and inhibitory activity of MOMIPP analogues against PIKFYVE determines their biological activity in cellular vacuolization, which is a hallmark of methuosis. ${ }^{1}$ The cytotoxic activity of MOMIPP (1a) and $\mathbf{2 b}$ may have additional target(s) and has unique pleiotropic effects on cells that lead to metabolic collapse and cell death. ${ }^{6}$ We showed that the inhibition of the PIKFYVE kinase activity results in cellular vacuolization, which is a contributing factor to methuosis.

PIKFYVE has also been reported to regulate TLR (toll-like receptor)-induced IL-12/23 expression by modulating PI(3)P and PI(3,5)P2 levels, and dysregulated TLR signaling can lead to autoimmune diseases such as Crohn's disease, rheumatoid arthritis, and psoriasis. ${ }^{13}$ Our study suggests that MOMIPP might be an important tool to study the function of the PIKFYVE lipid kinase activity in various biological processes including the TLR pathway regulation in IL-12/23-mediated diseases as well as methuosis.

\section{EXPERIMENTAL SECTION}

General Chemistry. All commercially available solvents (VWR and Fisher) and compounds (Fluka, Lancaster, Aldrich) were used as received. Compounds were synthesized according to the reported experimental procedures (Supporting Information). ${ }^{7}$ NMR spectra were recorded with a Bruker AV 400 spectrometer in the solvents indicated. Chemical shifts $(\delta)$ are given in ppm relative to trimethylsilane. All coupling constants $(J)$ are reported in hertz. The data are reported as follows: chemical shift, intergration, and multiplicity ( $\mathrm{s}=$ singlet, $\mathrm{d}=$ doublet, $\mathrm{t}=$ triplet, $\mathrm{q}=$ quartet, $\mathrm{m}=$ multiplet, and $\mathrm{b}=$ broad peak). High-resolution mass spectrometry (HRMS) was performed using electrospray ionization (ESI) in positive ion mode after separation by liquid chromatography (Nexera from Shimadzu). The elemental composition was derived from the mass spectra acquired at the high resolution of about 30000 on an LTQ Orbitrap XL mass spectrometer (Thermo Scientific). The high mass accuracy below $1 \mathrm{ppm}$ was obtained by using a lock mass. Preparatory silica gel chromatography was performed on a CombiFlash Rf 200 (Teledyne ISCO) flash chromatography system with RediSep Rf normal phase silica gel $(25-70 \mu \mathrm{m})$ columns and $254 \mathrm{~nm}$ UV detection.

To determine the chemical purity of final compounds, reverse-phase high-performance liquid chromatography (HPLC) analysis was performed. An ACQUITY UPLC HSS T3 column $(1.8 \mu \mathrm{m} ; 2.1 \times 100 \mathrm{~mm})$ and a mobile phase $(0.8$ $\mathrm{mL} / \mathrm{min}$ flow rate) were used with the following composition: eluent A (water $+0.05 \%$ formic acid $+3.75 \mathrm{mM}$ acetic acid), eluent B (acetonitrile $+0.04 \%$ formic acid), with gradient elution from 5 to $98 \%$ eluent B. HPLC was performed at $60^{\circ} \mathrm{C}$. As determined by HPLC, all compounds were of $95 \%$ or of a greater purity. Mass spectra were obtained with a Finnigan MAT $8200(70 \mathrm{eV})$ spectrometer with an ESI-MS source: Finnigan MAT 95 for accurate mass determination. The mass spectra $(m / z)$ were recorded using ESI.

Synthetic Protocols. 5-Methoxy-2-methyl-[1H]-indole-3carbaldehyde (4). To a dried two-neck round-bottom flask, flushed under argon at $0{ }^{\circ} \mathrm{C}, \mathrm{POCl}_{3}(0.25 \mathrm{~mL}, 2.68 \mathrm{mmol})$ was added to a solution of anhydrous dimethylformamide (DMF) 


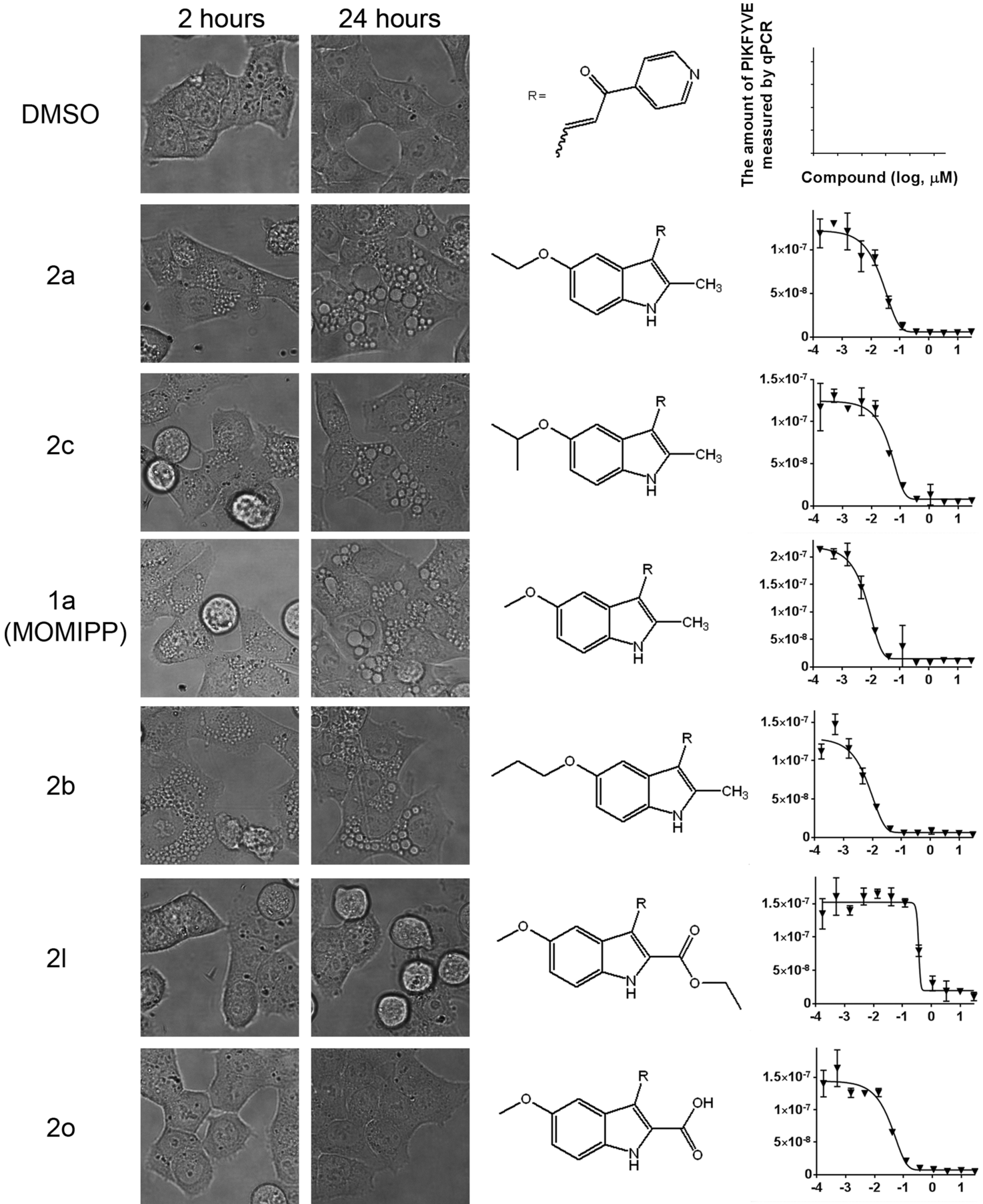

Figure 3. Vacuolization phenotype of compounds and its correlation to the PIKFYVE binding activity. Phase contrast images of live cells were obtained at 2 and $24 \mathrm{~h}$ after compound treatment as described in the Experimental Section at $40 \times$ magnification. The PIKFYVE binding assay with each compound was performed as described.

$(1 \mathrm{~mL})$ and stirred for $10 \mathrm{~min}$ before the dropwise addition of a solution of 5-methoxy-2-methyl-[1H]-indole $(100 \mathrm{mg}, 0.620$ $\mathrm{mmol}$ ) dissolved in anhydrous DMF $(2 \mathrm{~mL})$. The reaction mixture was then warmed to room temperature and stirred for an additional $30 \mathrm{~min}$. $\mathrm{NaOH}(1 \mathrm{~N}, 5 \mathrm{~mL})$ was added slowly, and the aqueous layer was extracted with dichloromethane $(\mathrm{DCM})(2 \times 25 \mathrm{~mL})$. The organic phases were combined, dried over $\mathrm{Na}_{2} \mathrm{SO}_{4}$, and concentrated under a reduced pressure to yield the corresponding compound (4) as a colorless oil (107 mg, 82\%). LC/MS (ESI) $m / z:(M+H)^{+}$190.2. The compound was taken to the next step without further purification.

(E)-3-(5-Methoxy-2-methyl-[1H]-indol-3-yl)-1-(pyridin-4yl)prop-2-en-1-one (1a). To a solution of 4 (105 mg, 0.555 $\mathrm{mmol})$ in anhydrous $\mathrm{MeOH}(3 \mathrm{~mL})$, pyrrolidine $(0.101 \mathrm{~mL}$, $1.221 \mathrm{mmol})$ and 4-acetylpyridine (168 $\mathrm{mg}, 1.387 \mathrm{mmol}$ ) were added. The mixture was then heated at $65{ }^{\circ} \mathrm{C}$ for $24 \mathrm{~h}$. As the reaction progressed, a precipitate was formed. When the reaction was complete, the precipitate was collected, washed with ice-cold $\mathrm{MeOH}(3 \times 10 \mathrm{~mL})$, and dried at room temperature for $24 \mathrm{~h}$ to yield $1 \mathrm{a}$ as a red solid $(111.3 \mathrm{mg}, 68 \%)$ : 

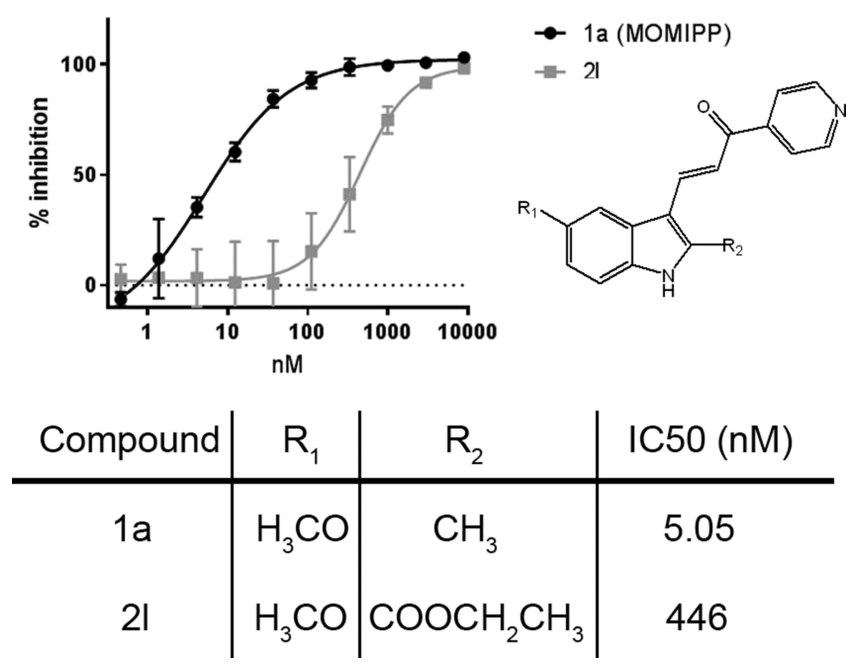

Figure 4. PIKFYVE inhibition by MOMIPP. The PIKFYVE inhibitory activity by compounds 1a (MOMIPP) and 21 was measured as described in the Experimental Section. Data are shown as percent inhibition of kinase activity calculated from the percent conversion of adenosine triphosphate (ATP) to adenosine diphosphate (ADP).

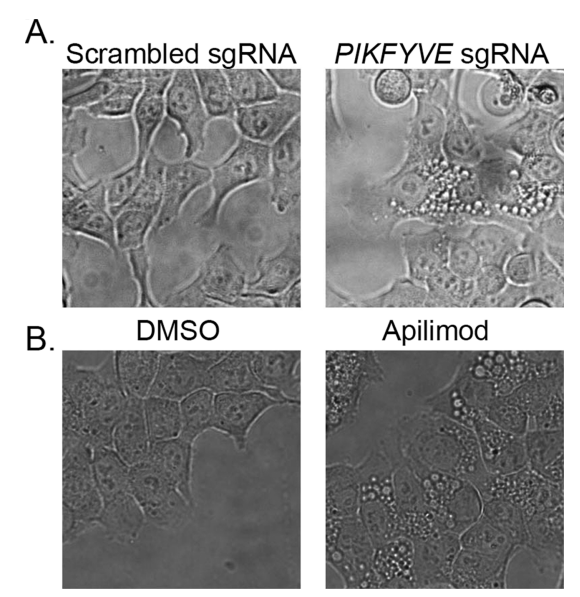

Figure 5. Genetic and chemical perturbations of PIKFYVE phenocopies the MOMIPP treatment. (A) Phase contrast images of HCT116 cells stably expressing scrambled single-guide RNA (sgRNA) or sgRNA targeting PIKFYVE. (B) Phase contrast images of HCT116 cells treated with DMSO or $5 \mathrm{nM}$ PIKFYVE inhibitor apilimod for $24 \mathrm{~h}$.

${ }^{1} \mathrm{H}$ NMR (400 MHz, DMSO-d $d_{6}$ ): $\delta 11.90$ (s, $\left.1 \mathrm{H}\right), 8.85-8.78$ (m, 2H), 8.09 (d, $J=15.3 \mathrm{~Hz}, 1 \mathrm{H}), 7.98-7.91(\mathrm{~m}, 2 \mathrm{H}), 7.44$ (d, $J=2.3 \mathrm{~Hz}, 1 \mathrm{H}), 7.41-7.28(\mathrm{~m}, 2 \mathrm{H}), 6.85$ (dd, $J=8.7,2.3$ $\mathrm{Hz}, 1 \mathrm{H}), 3.87$ (s, 3H), $2.58(\mathrm{~s}, 3 \mathrm{H}) .{ }^{13} \mathrm{C}$ NMR (101 MHz, DMSO- $\left.d_{6}\right): \delta 188.01,155.13,150.56,145.73,145.06,139.54$, 130.98, 126.55, 121.37, 112.77, 112.23, 110.86, 109.26, 103.47, 12.13. HPLC $(10 \mathrm{~min}): \mathrm{tR}=3.28 \mathrm{~min}$. HPLC purity $100 \%$. $\mathrm{LC} / \mathrm{MS}(\mathrm{ESI}) m / z:(\mathrm{M}+\mathrm{H})^{+}$293.2; HRMS (EI) $m / z$ : 293.12845 $[\mathrm{M}+\mathrm{H}]^{+}$calcd for $\mathrm{C}_{18} \mathrm{H}_{17} \mathrm{O}_{2} \mathrm{~N}_{2}$, 293.12845; found, 293.12845 .

(E)-3-(5-Ethoxy-2-methyl-1H-indol-3-yl)-1-(pyridin-4-yl)prop-2-en-1-one (2a). In a $20 \mathrm{~mL}$ pressure-release vial, 5ethoxy-2-methyl- $1 \mathrm{H}$-indole-3-carbaldehyde $4 \mathrm{a}(50 \mathrm{mg}, 0.25$ $\mathrm{mmol})$ was dissolved in anhydrous $\mathrm{MeOH}(2 \mathrm{~mL})$, followed by the addition of 4-acetylpyridine $(74.5 \mathrm{mg}, 0.62 \mathrm{mmol})$ and piperidine $(0.054 \mathrm{~mL}, 0.54 \mathrm{mmol})$. The solution was then heated at $65{ }^{\circ} \mathrm{C}$ for $24 \mathrm{~h}$. The reaction mixture was diluted with
DCM and purified using silica gel flash chromatography (0$100 \%$ EtOAc in heptane) to yield an orange solid $(9.7 \mathrm{mg}$, 13\%): ${ }^{1} \mathrm{H}$ NMR (400 MHz, DMSO- $d_{6}$ ): $\delta 11.88(\mathrm{~s}, 1 \mathrm{H}), 8.88-$ $8.73(\mathrm{~m}, 2 \mathrm{H}), 8.07$ (d, $J=15.3 \mathrm{~Hz}, 1 \mathrm{H}), 7.99-7.88(\mathrm{~m}, 2 \mathrm{H})$, $7.41(\mathrm{~d}, J=2.3 \mathrm{~Hz}, 1 \mathrm{H}), 7.37-7.26(\mathrm{~m}, 2 \mathrm{H}), 6.83$ (dd, $J=8.7$, $2.3 \mathrm{~Hz}, 1 \mathrm{H}), 4.13(\mathrm{q}, J=7.0 \mathrm{~Hz}, 2 \mathrm{H}), 2.57(\mathrm{~s}, 3 \mathrm{H}), 1.37(\mathrm{t}, J=$ $6.9 \mathrm{~Hz}, 3 \mathrm{H}) .{ }^{13} \mathrm{C}$ NMR $\left(101 \mathrm{MHz}, \mathrm{DMSO}-d_{6}\right): \delta 188.16$, $154.40,145.77,145.18,139.63,131.00,126.61,121.43,112.24$, $111.37,109.29,104.40,63.58,40.15,39.94,39.73,39.52,39.31$, $38.89,14.91,12.15$. HPLC $(5 \mathrm{~min}): \mathrm{tR}=1.59 \mathrm{~min}$, HPLC purity $98 \%$. LC/MS (ESI) $m / z:(\mathrm{M}+\mathrm{H})^{+} 307.1$; HRMS (EI) $m / z: 306.1368[\mathrm{M}+\mathrm{H}]^{+}$calcd for $\mathrm{C}_{19} \mathrm{H}_{18} \mathrm{~N}_{2} \mathrm{O}_{2}, 307.1447$; found, 307.1448 .

(E)-3-(2-Methyl-5-propoxy-1H-indol-3-yl)-1-(pyridin-4-yl)prop-2-en-1-one (2b). 2-Methyl-5-propoxy-[1H]-indole-3-carbaldehyde ( $80 \mathrm{mg}, 0.37 \mathrm{mmol}$ ) was reacted following the protocol described for $\mathbf{2 a}$ to yield the corresponding compound as a yellow solid (46.7 mg, 39\%): ${ }^{1} \mathrm{H}$ NMR (400 MHz, DMSO$\left.d_{6}\right): \delta 11.89(\mathrm{~s}, 1 \mathrm{H}), 8.85-8.78(\mathrm{~m}, 2 \mathrm{H}), 8.08(\mathrm{~d}, J=15.3 \mathrm{~Hz}$, $1 \mathrm{H}), 7.96-7.90(\mathrm{~m}, 2 \mathrm{H}), 7.41(\mathrm{~d}, J=2.3 \mathrm{~Hz}, 1 \mathrm{H}), 7.37-7.27$ $(\mathrm{m}, 2 \mathrm{H}), 6.85(\mathrm{dd}, J=8.7,2.3 \mathrm{~Hz}, 1 \mathrm{H}), 4.04(\mathrm{t}, J=6.5 \mathrm{~Hz}$, $2 \mathrm{H}), 2.58(\mathrm{~s}, 3 \mathrm{H}), 1.78(\mathrm{q}, J=6.8 \mathrm{~Hz}, 2 \mathrm{H}), 1.03(\mathrm{t}, J=7.4 \mathrm{~Hz}$, $3 \mathrm{H}) .{ }^{13} \mathrm{C}$ NMR $\left(101 \mathrm{MHz}, \mathrm{DMSO}-d_{6}\right): \delta 188.15,154.52$, $150.54,145.66,145.14,139.59,130.94,126.60,121.37,112.89$, $112.20,111.38,109.23,104.35,69.59,22.23,12.14,10.53$. HPLC $(10 \mathrm{~min}): \mathrm{tR}=4.27 \mathrm{~min}$, HPLC purity $100 \%$. LC/MS (ESI) $m / z:(\mathrm{M}+\mathrm{H})^{+}$321.3; HRMS (EI) $m / z: 321.15973[\mathrm{M}+$ $\mathrm{H}]^{+}$calcd for $\mathrm{C}_{20} \mathrm{H}_{21} \mathrm{O}_{2} \mathrm{~N}_{2}, 321.15975$; found, 321.15973 .

(E)-3-(5-Isopropoxy-2-methyl-1H-indol-3-yl)-1-(pyridin-4yl)prop-2-en-1-one (2c). 2-Methyl-5-propoxy-[1H]-indole-3carbaldehyde $(80 \mathrm{mg}, 0.37 \mathrm{mmol}$ ) was reacted following the protocol described for $\mathbf{2 a}$ to yield the corresponding compound as an orange solid $(2.0 \mathrm{mg}, 3 \%):{ }^{1} \mathrm{H}$ NMR (400 MHz, DMSO$\left.d_{6}\right): \delta 11.87(\mathrm{~s}, 1 \mathrm{H}), 8.84-8.79(\mathrm{~m}, 2 \mathrm{H}), 8.06(\mathrm{~d}, J=15.3 \mathrm{~Hz}$, $1 \mathrm{H}), 7.94-7.89$ (m, 2H), 7.41 (d, $J=2.3 \mathrm{~Hz}, 1 \mathrm{H}), 7.34-7.25$ $(\mathrm{m}, 2 \mathrm{H}), 6.83(\mathrm{dd}, J=8.7,2.3 \mathrm{~Hz}, 1 \mathrm{H}), 4.68(\mathrm{p}, J=6.1 \mathrm{~Hz}$, $1 \mathrm{H}), 3.30(\mathrm{~s}, 4 \mathrm{H}), 2.56(\mathrm{~s}, 3 \mathrm{H}), 1.30(\mathrm{~d}, J=6.0 \mathrm{~Hz}, 6 \mathrm{H})$. HPLC ( $5 \mathrm{~min}$ ): $\mathrm{tR}=1.74 \mathrm{~min}$; HPLC purity $100 \%$. LC/MS (ESI) $m / z:[\mathrm{M}+\mathrm{H}]^{+}$; HRMS (EI) $m / z: 321.2[\mathrm{M}+\mathrm{H}]^{+}$calcd for $\mathrm{C}_{20} \mathrm{H}_{20} \mathrm{~N}_{2} \mathrm{O}_{2}, 321.1643$; found, 321.1635 .

(E)-Ethyl 5-Methoxy-3-(3-oxo-3-(pyridin-4-yl)prop-1-en-1yl)-[1H]-indole-2-carboxylate (2l). Ethyl 3-formyl-5-methoxy$[1 \mathrm{H}]$-indole-2-carboxylate $(50 \mathrm{mg}, 0.202 \mathrm{mmol})$ was reacted following the protocol described for 1a using piperidine (2 equiv) instead of pyrrolidine to yield the desired product as a yellow solid (61.9 mg, 86\%): ${ }^{1} \mathrm{H}$ NMR (400 MHz, DMSO- $\left.d_{6}\right)$ : $\delta 12.5(\mathrm{~s}, 1 \mathrm{H}), 8.84(\mathrm{~d}, J=5.9 \mathrm{~Hz}, 2 \mathrm{H}), 8.74(\mathrm{~d}, J=16.0 \mathrm{~Hz}$, $1 \mathrm{H}), 7.93(\mathrm{~d}, J=5.9 \mathrm{~Hz}, 2 \mathrm{H}), 7.65(\mathrm{~d}, J=15.8 \mathrm{~Hz}, 1 \mathrm{H}), 7.57-$ $7.47(\mathrm{~m}, 2 \mathrm{H}), 7.09(\mathrm{~d}, J=8.9 \mathrm{~Hz}, 1 \mathrm{H}), 4.40(\mathrm{q}, J=7.1 \mathrm{~Hz}$, $2 \mathrm{H}), 3.91(\mathrm{~s}, 3 \mathrm{H}), 1.35(\mathrm{t}, J=7.1 \mathrm{~Hz}, 3 \mathrm{H}) .{ }^{13} \mathrm{C} \operatorname{NMR}(101$ $\left.\mathrm{MHz}, \mathrm{DMSO}-d_{6}\right): \delta 189.84,160.68,155.73,150.61,144.44$, $139.46,125.44,121.58,116.56,115.49,114.50,103.09,61.12$, $55.55,14.09$. HPLC $(10 \mathrm{~min}): \mathrm{tR}=4.45 \mathrm{~min}, \mathrm{HPLC}$ purity $100 \%$. LC/MS (ESI) $m / z: 351.3(\mathrm{M}+\mathrm{H})^{+}$; HRMS (EI) $m / z$ : $351.13393[\mathrm{M}+\mathrm{H}]^{+}$calcd for $\mathrm{C}_{20} \mathrm{H}_{19} \mathrm{O}_{4} \mathrm{~N}_{2}, 351.13393$; found, 351.13391.

Sodium (E)-5-Methoxy-3-(3-oxo-3-(pyridin-4-yl)prop-1-en1-yl)-[1H]-indole-2-carboxylate (2o). To a solution of 21 (20 $\mathrm{mg}, 0.057 \mathrm{mmol})$ in tetrahydrofuran/MeOH $(2: 1,3 \mathrm{~mL}), 4 \mathrm{~N}$ $\mathrm{NaOH}(0.071 \mathrm{~mL}, 0.285 \mathrm{mmol})$ was added at room temperature and further stirred for $4 \mathrm{~h}$ at $50{ }^{\circ} \mathrm{C}$ until completion of the reaction. The volatiles were then evaporated under a reduced pressure and cold diethyl ether $(10 \mathrm{~mL})$ was 
added. The resulting precipitate was collected and dried at room temperature for $24 \mathrm{~h}$ to yield the desired compound as a red solid sodium salt (15.9 mg, 77\%). ${ }^{1} \mathrm{H}$ NMR (400 MHz, DMSO- $\left.d_{6}\right): \delta 9.32(\mathrm{~d}, J=13.7 \mathrm{~Hz}, 1 \mathrm{H}), 8.69(\mathrm{~d}, J=5.9 \mathrm{~Hz}$, $2 \mathrm{H}), 7.77(\mathrm{~d}, J=5.7 \mathrm{~Hz}, 2 \mathrm{H}), 7.31(\mathrm{~d}, J=8.5 \mathrm{~Hz}, 1 \mathrm{H}), 7.25(\mathrm{~s}$, $1 \mathrm{H}), 6.88(\mathrm{~s}, 1 \mathrm{H}), 6.61(\mathrm{~d}, J=7.1 \mathrm{~Hz}, 1 \mathrm{H}), 3.81(\mathrm{~s}, 3 \mathrm{H}) .{ }^{13} \mathrm{C}$ NMR $\left(126 \mathrm{MHz}, \mathrm{DMSO}-d_{6}\right): \delta 189.63,163.52,155.44,150.95$, 146.13, 145.58, 130.58, 127.05, 122.02, 115.01, 114.01, 112.69, 111.00, 104.30, 55.97. HPLC $(10 \mathrm{~min}): \mathrm{tR}=3.10 \mathrm{~min}$, HPLC purity $>98 \%$. LC/MS (ESI) $m / z: 323.2(\mathrm{M}+\mathrm{H})^{+}$; HRMS (EI) $m / z: 323.10272[\mathrm{M}+\mathrm{H}]^{+}$calcd for $\mathrm{C}_{18} \mathrm{H}_{15} \mathrm{O}_{4} \mathrm{~N}_{2}, 323.10263$; found, 323.10272 .

Lipid Kinase Competition Assay. Lipid kinase competition assay for 22 inositol kinases including clinically relevant mutants were performed using DiscoveRX KINOMEscan profiling. Briefly, streptavidin-coated magnetic beads were treated with biotinylated positive control compounds (compounds that specifically bind each kinase) to generate affinity resins. Binding reactions were performed by combining DNAtagged kinases, liganded affinity beads, and test compounds. After binding, DNA-tagged kinases were eluted and each kinase concentration in the eluates was measured by qPCR of DNA tag on each kinase.

Cell Viability Assay. Cells were plated into each well of Greiner 384-well plates at a density of 1500 cells/well. The cells were incubated with increasing concentration of compounds $(0.1 \% \mathrm{v} / \mathrm{v} \mathrm{DMSO})$ for $72 \mathrm{~h}$, and cell viability was measured by an EnVison plate reader (PerkinElmer) with CellTiter-Glo (Promega).

Cell Morphology. For acquisition of phase contrast images of live cells, HCT116 cells were seeded on a 384-well highcontent imaging microplate. Next day, the compounds were added and images were obtained at the indicated time after the addition of compounds using an EVOS FL Cell Imaging System (Life Technologies, Paisley, UK).

PIKFYVE Inhibition Assay. The kinase inhibition assay was performed using an ADP-Glo system (Promega) according to the manufacturer protocol. Briefly, the kinase reaction was performed by adding the active PIKFYVE protein (SignalChem), lipid substrate PI(3)P (SignalChem), protein kinase C lipid activator (SignalChem), and $50 \mu \mathrm{M}$ ATP (SignalChem) in kinase buffer ( $25 \mathrm{mM}$ MOPS ( $\mathrm{pH} 7.2$ ), $12.5 \mathrm{mM} \beta$-glycerolphosphate, $25 \mathrm{mM} \mathrm{MgCl}_{2}, 5 \mathrm{mM}$ egtazic acid, $2 \mathrm{mM}$ ethylenediaminetetraacetic acid, and $0.25 \mathrm{mM}$ dithiothreitol). The reaction was terminated by adding the ADP-Glo reagent (Promega). The ATP-ADP conversion was quantitated by adding the kinase detection reagent (Promega) and reading the luminescence signal with the plate reader (EnVision).

PIKFYVE KnockOut. Pooled PIKFYVE-/- cells were generated using CRISPR-Cas9-mediated knockout. HCT116 cells stably expressing Cas9 were transduced with lentivirus containing sgRNA against PIKFYVE. sgRNA with a scrambled sequence was used as a control.

\section{ASSOCIATED CONTENT}

\section{S Supporting Information}

The Supporting Information is available free of charge on the ACS Publications website at DOI: 10.1021/acsomega.8b00202.

Synthetic protocol scheme, ${ }^{1} \mathrm{H}$ NMR spectra, HPLC spectra, and HRMS spectra of compounds 1a, 2a, 2b, 2c, 2l, and 2o (PDF)

\section{AUTHOR INFORMATION}

\section{Corresponding Authors}

*E-mail: hyelim.cho@merck.com. Phone: 1-857-300-7644 (H.C.).

*E-mail: marc.hild@novartis.com. Phone: 1-617-871-7511 (M.H.).

*E-mail: jeremy.jenkins@novartis.com. Phone: 1-617-871-7155 (J.L.J.).

ORCID $\odot$

Hyelim Cho: 0000-0002-1331-3378

Present Addresses

${ }^{\S}$ Department of Pharmacology, Merck Research Laboratories, 33 Avenue Louis Pasteur, Boston, Massachusetts 02115, USA (H.C.).

"Department of Scientific Computing, Vertex Pharmaceuticals, 50 Northern Avenue, Boston, Massachusetts 02210, USA (E.G.).

\section{Author Contributions}

H.C. designed and led the study under the supervision of J.L.J. and M.H. M.P. and A.R. synthesized the compounds under the supervision of R.M. R.M. and E.G. contributed to the study design. H.C. wrote the manuscript with input from all authors. All authors gave approval to the final version of the manuscript.

\section{Notes}

The authors declare the following competing financial interest(s): The authors (H.C., E.G., R.M., M.H., and J.L.J.) were employees of Novartis during the time of this study. The research was fully funded by the Novartis Institutes for Biomedical Research.

\section{ACKNOWLEDGMENTS}

We thank the teams of High-Throughput Biology and Screening Informatics (Novartis, Cambridge, USA) for the collaboration and support.

\section{ABBREVIATIONS}

SAR, structure-activity relationship; MOMIPP, 3-(5-methoxy2-methyl-1H-indol-3-yl)-1-(4-pyridinyl)-2-propene-1-one; CRISPR, clustered regularly interspaced short palindromic repeats; sgRNA, single-guide RNA; TLR, toll-like receptor; qPCR, quantitative PCR; CD, Crohn's disease; RA, rheumatoid arthritis

\section{REFERENCES}

(1) Maltese, W. A.; Overmeyer, J. H. Methuosis: Nonapoptotic Cell Death Associated with Vacuolization of Macropinosome and Endosome Compartments. Am. J. Pathol. 2014, 184, 1630-1642.

(2) Overmeyer, J. H.; Kaul, A.; Johnson, E. E.; Maltese, W. A. Active Ras Triggers Death in Glioblastoma Cells through Hyperstimulation of Macropinocytosis. Mol. Cancer Res. 2008, 6, 965-977.

(3) Chi, S.; Kitanaka, C.; Noguchi, K.; Mochizuki, T.; Nagashima, Y.; Shirouzu, M.; Fujita, H.; Yoshida, M.; Chen, W.; Asai, A.; Himeno, M.; Yokoyama, S.; Kuchino, Y. Oncogenic Ras Triggers Cell Suicide through the Activation of a Caspase-Independent Cell Death Program in Human Cancer Cells. Oncogene 1999, 18, 2281-2290.

(4) Bhanot, H.; Young, A. M.; Overmeyer, J. H.; Maltese, W. A. Induction of Nonapoptotic Cell Death by Activated Ras Requires Inverse Regulation of Rac1 and Arf6. Mol. Cancer Res. 2010, 8, 13581374.

(5) Robinson, M. W.; Overmeyer, J. H.; Young, A. M.; Erhardt, P. W.; Maltese, W. A. Synthesis and Evaluation of Indole-Based Chalcones as Inducers of Methuosis, a Novel Type of Nonapoptotic Cell Death. J. Med. Chem. 2012, 55, 1940-1956. 
(6) Trabbic, C. J.; Dietsch, H. M.; Alexander, E. M.; Nagy, P. I.; Robinson, M. W.; Overmeyer, J. H.; Maltese, W. A.; Erhardt, P. W. Differential Induction of Cytoplasmic Vacuolization and Methuosis by Novel 2-Indolyl-Substituted Pyridinylpropenones. ACS Med. Chem. Lett. 2014, 5, 73-77.

(7) Trabbic, C. J.; Overmeyer, J. H.; Alexander, E. M.; Crissman, E. J.; Kvale, H. M.; Smith, M. A.; Erhardt, P. W.; Maltese, W. A. Synthesis and Biological Evaluation of Indolyl-Pyridinyl-Propenones Having Either Methuosis or Microtubule Disruption Activity. J. Med. Chem. 2015, 58, 2489-2512.

(8) Trabbic, C. J.; George, S. M.; Alexander, E. M.; Du, S.; Offenbacher, J. M.; Crissman, E. J.; Overmeyer, J. H.; Maltese, W. A.; Erhardt, P. W. Synthesis and Biological Evaluation of Isomeric Methoxy Substitutions on Anti-Cancer Indolyl-Pyridinyl-Propenones: Effects on Potency and Mode of Activity. Eur. J. Med. Chem. 2016, 122, 79-91.

(9) Billcliff, P. G.; Lowe, M. Inositol Lipid Phosphatases in Membrane Trafficking and Human Disease. Biochem. J. 2014, 461, 159-175.

(10) De Craene, J.-O.; Bertazzi, D. L.; Bär, S.; Friant, S. Phosphoinositides, Major Actors in Membrane Trafficking and Lipid Signaling Pathways. Int. J. Mol. Sci. 2017, 18, 634.

(11) Maltese, W. A.; Overmeyer, J. H. Non-Apoptotic Cell Death Associated with Perturbations of Macropinocytosis. Front. Physiol. 2015, 6, 38 .

(12) Compton, L. M.; Ikonomov, O. C.; Sbrissa, D.; Garg, P.; Shisheva, A. Active Vacuolar H + ATPase and Functional Cycle of Rab5 Are Required for the Vacuolation Defect Triggered by PtdIns(3,5)P 2 Loss under PIKfyve or Vps34 Deficiency. Am. J. Physiol.: Cell Physiol. 2016, 311, C366-C377.

(13) Cai, X.; Xu, Y.; Cheung, A. K.; Tomlinson, R. C.; AlcázarRomán, A.; Murphy, L.; Billich, A.; Zhang, B.; Feng, Y.; Klumpp, M.; Rondeau, J.-M.; Fazal, A. N.; Wilson, C. J.; Myer, V.; Joberty, G.; Bouwmeester, T.; Labow, M. A.; Finan, P. M.; Porter, J. A.; Ploegh, H. L.; Baird, D.; De Camilli, P.; Tallarico, J. A.; Huang, Q. PIKfyve, a Class III PI Kinase, Is the Target of the Small Molecular IL-12/IL-23 Inhibitor Apilimod and a Player in Toll-like Receptor Signaling. Chem. Biol. 2013, 20, 912-921.

(14) Shisheva, A. PIKfyve: Partners, Significance, Debates and Paradoxes. Cell Biol. Int. 2008, 32, 591-604. 